\title{
ANALISIS RASIO KEUANGAN ANGGARAN PENDAPATAN DAN BELANJA DAERAH (APBD) KOTA MANADO UNTUK MENILAI KINERJA KEUANGAN PEMERINTAH KOTA MANADO TAHUN ANGGARAN 2011 - 2015
}

\author{
Juddy Julian Pilat ${ }^{1}$, Jenny Morasa ${ }^{2}$ \\ ${ }^{1}$ Bagian Infrastruktur Kawasan Perkotaan, Pemerintah Kota Manado, Manado, Indonesia \\ ${ }^{2}$ Jurusan Akuntansi, Fakultas Ekonomi dan Bisnis, Universitas Sam Ratulangi, Jl. Kampus Bahu, Manado, \\ 95115, Indonesia \\ E-mail : jjulian189@gmail.com
}

\begin{abstract}
This study aims to assess the financial performance of Manado City Government using Financial Ratio Analysis of Regional Budget for Fiscal Year 2011-2015. Type of research is the descriptif qualitative with case study approach. The processed data is the Budget Realization Report of Manado City Government for Fiscal Year 2011-2015 were obtained from the internet publication on the official website of Financial Management Board and Regional Property of Manado City. The analysis used to analyze the Regional Financial Performance is Financial Ratio Analysis by calculate the Ratio of Independence, Degree of Fiscal Decentralization, Ratio of Effectiveness, Ratio of Efficiency and Ratio of Expenditure Congruence. While the analysis used to analyze the Ability of Regional Finance is to calculate the Share and Growth, Map of Regional Finance Capability and Financial Capability Index. Based on the calculation and analysis of the Regional Financial Performance can be concluded that the pattern of the region's autonomy level relationships in Manado City is instructive criteria. Degree of Fiscal Decentralization is still lacking, but the Ratio of Effectiveness is very effective and the Ratio of Efficiency is also very efficient. Ratio of Expenditure Congruence shows the balance between expenditures are not balanced. Based on the calculation and analysis of the Regional Financial Capability can be concluded, that the condition of financial ability of Manado City is still not ideal. Share and Growth calculation results, the position of Manado City is in quadrant II and Financial Capability Index of Manado City is high.

Keywords: Financial Ratio Analysis of Regional Budget, Financial Performance of Local Government.
\end{abstract}

\section{PENDAHULUAN}

Dalam menjalankan Otonomi Daerah, Pemerintah Daerah dituntut untuk menjalankan roda pemerintahan yang efektif dan efisien, sehingga mampu mendorong masyarakat untuk berperan serta dalam melaksanakan pembangunan. Pemerintah Daerah juga dituntut untuk meningkatkan pemerataan dan keadilan,sehingga dapat mengembangkan seluruh potensi yang dimiliki oleh masing-masing daerah. Tuntutan yang tinggi terhadap kinerja dan akuntabilitas kinerja daerah ini berujung pada kebutuhan pengukuran kinerja Pemerintah Daerah. Untuk itu, pemerintah dituntut untuk mampu membangun ukuran kinerja yang baik.

Salah satu teknik yang paling banyak digunakan untuk menganalisis laporan keuangan adalah Analisis Rasio Keuangan. Analisis Rasio Keuangan adalah suatu ukuran untuk mengidentifikasi ciri-ciri keuangan berdasarkan laporan keuangan yang tersedia. Analisis Rasio Keuangan terhadap Anggaran Pendapatan dan Belanja Daerah (APBD) dilakukan dengan cara menghitung Kinerja Keuangan Daerah dan Kemampuan Keuangan Daerah. Ada beberapa cara untuk menghitung Kinerja Keuangan Daerah, diantaranya adalah dengan mengitung Rasio Kemandirian, Rasio Derajat Desentralisasi Fiskal, Rasio Efektifitas, 
Rasio Efisiensi dan Rasio Keserasian Belanja Anggaran Pendapatan dan Belanja Daerah. Sedangkan untuk menghitung Kemampuan Keuangan Daerah, yaitu dengan cara menghitung Share dan Growth, Peta KemampuanKeuangan Daerah, dan Indeks Kemampuan Keuangan Anggaran Pendapatandan Belanja Daerah. Kemudian dari masing-masing perhitungan dilakukan evaluasi dengan cara membandingkan hasil yang dicapai oleh suatu daerah dari satu periode terhadap periode-periode sebelumnya, sehingga dapat diketahui bagaimana kecenderungan yang terjadi. Analisis Rasio Keuangan Anggaran Pendapatan dan Belanja Daerah (APBD) diharapkan dapat menjadi suatu alat ukur untuk menilai kinerja keuangan Pemerintah Daerah yang memiliki andil terbesar dalam upaya perkembangan suatu daerah. Berdasarkan latar belakang di atas, masalah dalam penelitian ini dirumuskan sebagai berikut.

1. Bagaimanakah Kinerja Keuangan Daerah Pemerintah Kota Manado berdasarkan hasil perhitungan Rasio Kemandirian, Rasio Derajat Desentralisasi Fiskal, Rasio Efektifitas, Rasio Efisiensi dan Rasio Keserasian Belanja APBD Kota Manado selama Tahun Anggaran 2011 sampai dengan 2015?

2. Bagaimanakah Kemampuan Keuangan Daerah Pemerintah Kota Manado diukur melalui Share dan Growth APBD, Peta Kemampuan Keuangan Daerah dan Indeks Kemampuan Keuangan(IKK) selama Tahun Anggaran 2011 sampai dengan 2015?

\section{TINJAUAN PUSTAKA}

\subsection{Pengukuran Kinerja Pemerintah Daerah}

Sistem pengukuran kinerja sektor publik adalah sistem yang bertujuan untuk membantu manajer publik menilai pencapaian suatu strategi melalui alat ukur finansial dan non-finansial. Pengukuran kinerja sektor publik dilakukan untuk memenuhi tiga maksud. Pertama, pengukuran kinerja sektor publik dimaksudkan untuk membantu memperbaiki kinerja pemerintah. Ukuran kinerja dimaksudkan untuk dapat membantu pemerintah berfokus pada tujuan dan sasaran program unit kerja. Hal ini pada akhirnya akan meningkatkan efisiensi dan efektivitas organisasi sektor publik dalam memberikan pelayanan sektor publik. Kedua, ukuran kinerja sektor publik digunakan untuk mengalokasikan sumber daya dan pembuatan keputusan. Ketiga, ukuran kinerja sektor publik dimaksudkan untuk mewujudkan pertanggungjawaban publik dan memperbaiki komunikasi kelembagaan (Ulum, 2009:19-21).

\subsection{Laporan Keuangan Pemerintah Daerah}

Berdasarkan Peraturan Pemerintah Nomor 71 Tahun 2010 Tentang Standar Akuntansi Pemerintahan, laporan keuangan pemerintah terdiri dari laporan pelaksanaan anggaran (budgetary reports), laporan finansial dan Catatan atas Laporan Keuangan (CaLK). Laporan pelaksaaan anggaran terdiri dari Laporan Realisasi Anggaran (LRA) dan Laporan Perubahan Saldo Anggaran Lebih (SAL). Laporan finansial terdiri dari Neraca, Laporan Operasional (LO), Laporan Perubahan Ekuitas (LPE) dan Laporan Arus Kas. CaLK merupakan laporan yang merinci atau menjelaskan lebih lanjut atas pos-pos laporan pelaksanaan anggaran maupun laporan finansial dan merupakan laporan yang tidak terpisahkan dari laporan pelaksanaan anggaran maupun laporan finansial.

\subsection{Anggaran Pendapatan dan Belanja Daerah}

Menurut Mahsun, Firma dan Heribertus (2011:81), Anggaran Pendapatan dan Belanja Daerah adalah daftar yang memuat rincian penerimaan daerah dan pengeluaran/belanja daerah selama satu tahun. Anggaran Pendapatan dan Belanja Daerah ditetapkan dengan peraturan daerah untuk masa satu tahun, mulai dari 1 Januari sampai dengan tanggal 31 Desember. Dalam Peraturan Menteri Dalam Negeri Republik Indonesia Nomor 37 Tahun 2014 Tentang Pedoman PenyusunanAnggaran Pendapatan dan Belanja Daerah Tahun Anggaran 2015 Pasal 1 Ayat 1, pengertian Anggaran Pendapatan dan Belanja Daerah adalah rencana keuangan tahunan pemerintahan daerah yang dibahas dan disetujui bersama oleh Pemerintah Daerah dan DPRD, dan ditetapkan dengan peraturan daerah. 


\subsection{Analisis Laporan Keuangan}

Salah satu teknik untuk melakukan Analisis Laporan Keuangan, yaitu dengan melakukan perhitungan Rasio Keuangan. Rasio keuangan adalah angka yang diperoleh dari hasil perbandingan dari satu pos laporan keuangan dengan pos lainnya yang mempunyai hubungan yang relevan dan signifikan. Rasio keuangan ini hanya menyederharnakan informasi yang menggambarkan hubungan antara pos tertentu dengan pos lainnya. Dengan penyederhanaan ini kita dapat menilai secara cepat hubungan antara pos tadi dan dapat membandingkannya dengan rasio lain sehingga kita dapat memperoleh informasi dan memberikan penilaian. Penelitian ini hanya dibatasi pada perhitungan Rasio Keuangan terhadap Laporan Realisasi Anggaran Pendapatan dan Belanja Daerah Tahun Anggaran 2011-2015. Analisis Rasio Keuangan digunakan untuk mengukur Kinerja Keuangan Daerah dan Kemampuan Keuangan Daerah.Analisis Kinerja Keuangan adalah usaha mengidentifikasi ciri-ciri keuangan berdasarkan laporan keuangan yang tersedia. Dalam organisasi pemerintah untuk mengukur kinerja keuangan ada beberapa ukuran kinerja, yaitu :

1. Rasio Kemandirian Keuangan Daerah

$$
\text { Rasio Kemandirian }=\frac{\text { Pendapatan Asli Daerah }}{\text { Bantuan Pemerintah Pusat/Propinsi dan Pinjaman }} \text { X 100\% }
$$

2. Rasio Derajat Desentralisasi Fiskal

$$
\text { Derajat Desentralisasi Fiskal }=\frac{\text { Pendapatan Asli Daerah }}{\text { Total Pendapatan Daerah }} \times 100 \%
$$

\section{Rasio Efektifitas}

$$
\text { Rasio Efektifitas }=\frac{\text { Realisasi Penerimaan PAD }}{\text { Target Penerimaan PAD berdasarkan Potensi Riil Daerah }} \text { X 100\% }
$$

4. Rasio Efisiensi

$$
\text { Rasio Efisiensi }=\frac{\text { Biaya yang dikeluarkan untuk memungut PAD }}{\text { Realisasi Penerimaan PAD }} \times 100 \%
$$

5. Rasio Keserasian Belanja

$$
\begin{aligned}
& \text { Rasio Belanja Tidak Langsung terhadap } \\
& \text { Total Belanja }
\end{aligned}=\frac{\text { Total Belanja Tidak Langsung }}{\text { Total Belanja Daerah }} \text { X 100\% }
$$

Rasio Belanja Langsung terhadap Total Belanja $=\frac{\text { Total Belanja Langsung }}{\text { Total Belanja Daerah }} \times 100 \%$

Analisis Kemampuan Keuangan Daerah dilakukan dengan cara:

1. Perhitungan dan Analisis Share dan Growth

$$
\begin{gathered}
\text { Share }=\frac{\text { PAD }}{\text { Total Belanja }} \times 100 \% \\
\text { Growth }=\frac{\text { PAD }_{\mathrm{i}}}{\text { PAD }_{\mathrm{i}-1}} \times 100 \%
\end{gathered}
$$


2. Peta Kemampuan Keuangan
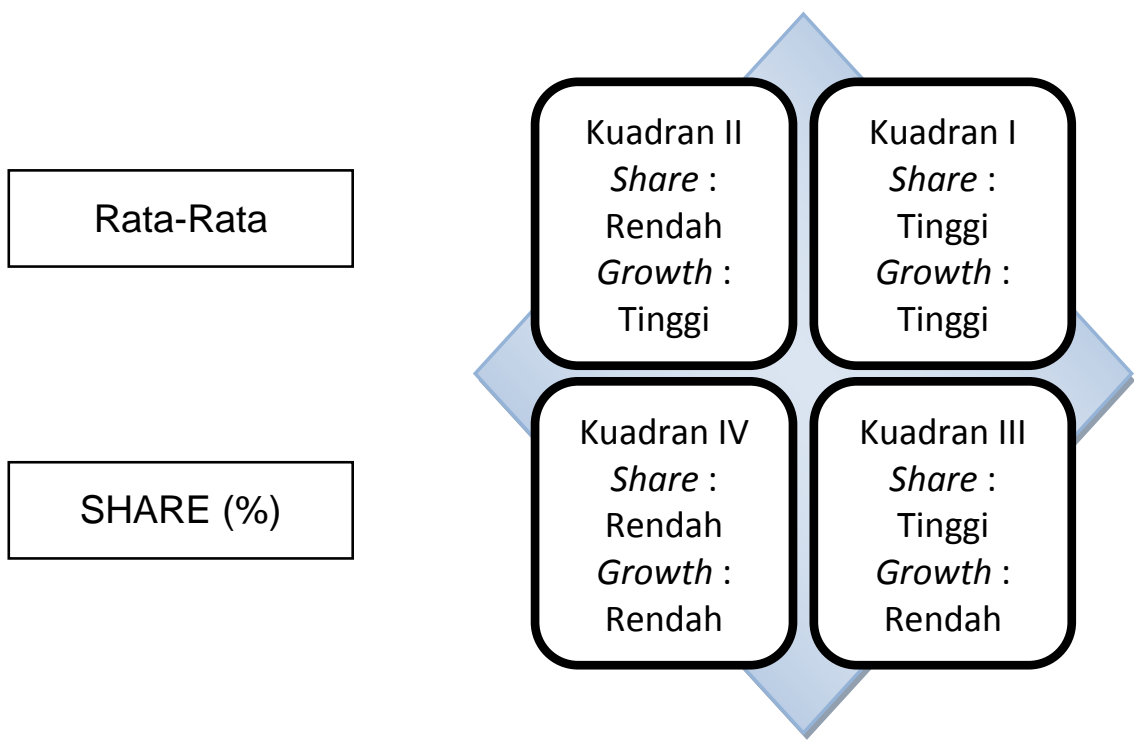

3. Indeks Kemampuan Keuangan

Indeks $X=\frac{(\text { Nilai } x \text { Hasil Pengukuran })-(\text { Nilai } \times \text { Kondisi Minimum })}{\text { (Nilai } \mathrm{x} \text { Kondisi Maksimum)-(Nilai } \mathrm{x} \text { Kondisi Minimum })}$

$$
\mathrm{IKK}=\frac{\mathrm{XG}+\mathrm{XE}+\mathrm{XS}}{3}
$$

\subsection{Penelitian Terdahulu}

Penelitian Aulia Zhufinsa Nur Rahmatina (2011) yang berjudul “Analisis Rasio Keuangan Anggaran Pendapatan dan Belanja Daerah Kota Bandung Tahun Anggaran 20052009”. Hasil yang didapat dalam penelitian tersebut adalah: a. Kemandirian Pemerintah Kota Bandung dalam memenuhi kebutuhan dana untuk penyelenggaraan tugas-tugas pemerintahan, pembangunan, dan pelayanan sosial masyarakat masih berada pada kemampuan keuangan yang rendah; b. Dalam merealisasikan pendapatan daerahnya, Pemerintah Kota Bandung sudah dapat dikategorikan efektif dan efisien; c. Berdasarkan perhitungan pada rasio aktivitas, dapat disimpulkan bahwa Pemerintah Kota Bandung masih memprioritaskan anggarannya untuk mencukupi Belanja Rutin dibandingkan Belanja Pembangunan; d. Menurut hasil perhitungan DSCR yang memenuhi syarat untuk melakukan pinjaman adalah Tahun Anggaran 2006, dengan maksimal angsuran pokok pinjaman sebesar Rp 32.394.659.049,60. Sedangkan untuk Tahun Anggaran yang lain, tidak boleh meminjam lagi karena DSCR di bawah 2,5; e. Rasio Pertumbuhan PAD menunjukkan angka yang meningkat setiap tahunnya. Begitu juga dengan Rasio Pertumbuhan Total Pendapatan Kota Bandung selama Tahun Anggaran 2005-2009 yang mengalami kenaikan, yang kemudian akan mempengaruhi Rasio Pertumbuhan Belanja Rutin yang juga mengalami peningkatan setiap tahunnya. Sedangkan untuk Rasio Pertumbuhan Belanja Pembangunan Tahun Anggaran 2006 sempat terjadi penurunan, namun pada 3 (tiga) Tahun Anggaran berikutnya mengalami peningkatan jumlah nominal belanja pembangunan.

Penelitian Filip Hrúza (2015) yang berjudul "Public Sector Organization Financial Ratios' Recent Development As A Matter Of Financial Innovation". Hasil yang didapat dalam penelitian tersebut adalah:

a. With the increasing volume of financial resources, financial information and the growing complexity of financial relations within the national economy's demand for financial analytical tools will increasingly grow; $b$. According to municipal financial management, it 
would also be beneficial not to underestimate the external design and internal coherence of the concept applied.

Penelitian Irwan Taufiq Ritonga (Indonesia), Colin Clark (Australia), Guneratne Wickremasinghe (Australia) (2012) yang berjudul "Assessing financial condition of local government in Indonesia:an exploration". Hasil yang didapat dalam penelitian tersebut adalah: a. The explorationshows that local governments have good financialcondition for the dimensions of short-term solvency,long-term solvency, and financial flexibility; b. An adequate financial condition exists for budgetary solvency as the local governments can cover all expenditures. However, local governments have weak financial independence because they can only control around 8\% of their revenues. For the dimension of service level solvency, it cannot be concluded whether the existing condition of local government is good or not because there is no threshold that distinguishes good and a weak financial condition. However, in general, there is an improvement in delivering services to the community as indicated by the increasing trend of the ratios of service level solvency; c. Finally, this study finds that stakeholders of local government in Indonesia perceive the dimension of long-term solvency and short-term solvency are the two most importance dimensions and the dimension of service level solvency is considered as the least importance of elements of the financial condition. These facts indicate that the stakeholders tend to have short-term horizon rather than long-term in managing local government finance.

\subsection{Kerangka Konseptual}

Kemampuan Pemerintah Daerah dalam mengelola keuangan termuat dalam Anggaran Pendapatan dan Belanja Daerah (APBD) yang menggambarkan kemampuan Pemerintah Daerah dalam membiayai kegiatan pelaksanaan tugas pembangunan. Dalam menjalankan Otonomi Daerah, Pemerintah Daerah dituntut untuk menjalankan roda pemerintahan yang efektif dan efisien sehingga mampu mendorong peran serta masyarakat dalam pembangunan, serta meningkatkan pemerataan dan keadilan yang mengembangkan seluruh potensi yang dimiliki oleh masing-masing daerah. Dalam pelaksanaan pembangunan daerah dibutuhkan anggaran biaya lebih untuk memperoleh hasil yang maksimal. Setiap tahun kota Manado melakukan perubahan-perubahan untuk memperbaiki maupun menambah fasilitas umum. Pembangunan tersebut pastilah berpengaruh pada besarnya jumlah dana yang dikeluarkan. Besar kecilnya rasio Anggaran Pendapatan dan Belanja Daerah (APBD) dari tahun ke tahun dijadikan pembuktian apakah kinerja Pemerintah Daerah sudah sesuai atau belum, dilihat dari perkembangan daerah tersebut.

Jalan keluar dari permasalahan tersebut adalah Pemerintah Daerah harus mampu untuk mengidentifikasi perkembangan kinerjanya dari tahun ke tahun. Salah satu alat untuk menganalisis kinerja Pemerintah Daerah dalam mengelola keuangan daerahnya adalah dengan melakukan analisis rasio keuangan terhadap Anggaran Pendapatan dan Belanja Daerah. Analisis rasio tersebut dapat dijadikan tolok ukur apakah kinerja Pemerintah Daerah meningkat dari tahun ke tahun, sehingga dapat dikatakan sebagai daerah yang berkembang. Terlebih lagi banyak sekali masyarakat yang belum mengetahui secara transparan mengenai besarnya dana yang dikeluarkan pemerintah dalam melaksanakan pembangunan, serta pengaruhnya terhadap ukuran kinerja Pemerintah Daerah.

Data yang digunakan dalam penelitian ini merupakan Laporan Realisasi Anggaran Pemerintah Kota Manado Tahun Anggaran 2011-2015 dan akan dianalisis menggunakan Rasio Kemandirian, Rasio Derajat Desentralisasi Fiskal, Rasio Efektivitas, Rasio Efisiensi, Rasio Keserasian Belanja, Share dan Growth APBD, Peta Kemampuan Keuangan Daerah dan Indeks Kemampuan Keuangan (IKK). Hasil perhitungan analisis ini akan digunakan untuk mengukur kinerja keuangan Pemerintah Kota Manado, yang kemudian akan disimpulkan dengan cara melihat grafik perbandingan rasio-rasio dari setiap periode selama 5 (lima) tahun. 


\subsection{Pertanyaan Riset}

Pertanyaan riset ditetapkan berdasarkan rumusan masalah yang telah dikemukakan dalam latar belakang penelitian, yaitu sebagai berikut.

1. Bagaimanakah Kinerja Keuangan DaerahPemerintah Kota Manado berdasarkan hasil perhitungan Rasio KemandirianAPBD Kota Manado selamaTahun Anggaran 2011 sampai dengan 2015?

2. Bagaimanakah Kinerja Keuangan DaerahPemerintah Kota Manado berdasarkan hasil perhitungan Rasio DerajatDesentralisasi Fiskal APBD Kota Manado selama Tahun Anggaran 2011 sampai dengan 2015?

3. Bagaimanakah Kinerja Keuangan Pemerintah Daerah Kota Manado berdasarkan hasil perhitungan Rasio EfektivitasAPBD Kota Manado selamaTahun Anggaran 2011 sampai dengan 2015?

4. Bagaimanakah Kinerja Keuangan Pemerintah Daerah Kota Manado berdasarkan hasil perhitungan Rasio EfisiensiAPBD Kota Manado selamaTahun Anggaran 2011 sampai dengan 2015?

5. Bagaimanakah Kinerja Keuangan Pemerintah Daerah Kota Manado berdasarkan hasil perhitungan Rasio KeserasianBelanja APBD Kota Manado selama Tahun Anggaran 2011 sampai dengan 2015?

6. Bagaimanakah Kemampuan Keuangan DaerahPemerintah Kota Manado diukur melalui Share dan Growth APBD Kota Manado selama Tahun Anggaran 2011 sampai dengan2015?

7. Bagaimanakah Kemampuan Keuangan DaerahPemerintah Kota Manado diukur melalui Peta Kemampuan Keuangan DaerahAPBD Kota Manado selama Tahun Anggaran2011 sampai dengan 2015?

8. Bagaimanakah Kemampuan Keuangan DaerahPemerintah Kota Manado diukur melalui Indeks Kemampuan Keuangan (IKK)APBD Kota Manado selama Tahun Anggaran2011 sampai dengan 2015?

\subsection{Proposisi}

Proposisi yang dapat ditetapkan sebagai pernyataan awal untuk menjawab pertanyaan riset dan memberikan solusi terhadap permasalahan dalam penelitian ini adalah sebagai berikut.

1. Rasio kemandirian Pemerintah Kota Manado diindikasikan sangat rendah, karena masih bergantung pada bantuan Pemerintah Pusat.

2. Rasio Derajat Desentralisasi Fiskal Pemerintah Kota Manado diindikasikan rendah sehingga belum mampu melaksanakan desentralisasi secara maksimal.

3. Rasio Efektifitas Pemerintah Kota Manado diindikasikan efektif dalam mengelola Pendapatan Asli Daerah (PAD).

4. Rasio Efisiensi Pemerintah Kota Manado diindikasikan efisien dalam mengelola biaya yang dikeluarkan untuk memungut PAD.

5. Rasio Keserasian Belanja Pemerintah Kota Manado diindikasikan tidak seimbang, karena belanja tidak langsung masih lebih dibandingkan belanja langsung.

6. Share PAD rendah dan Growth PAD tinggi yang mengindikasikan kondisi yang belum ideal.

7. Peta Kemampuan Keuangan Daerah Pemerintah Kota Manado menggambarkan ketidakmampuan PAD untuk memenuhi kebutuhan belanja.

8. Indeks Kemampuan Keuangan Pemerintah Kota Manado sangat tinggi, karena besarnya bantuan dana dari Pemerintah Pusat. 


\section{METODE PENELITIAN}

\subsection{Jenis Penelitian}

Metode yang digunakan dalam penelitian ini adalah metode kualitatif deskriptif. Penelitian dengan menggunakan metode ini bertujuan untuk menggambarkan, meringkaskan berbagai kondisi, berbagai situasi atau berbagai fenomena realitas sosial yang ada di masyarakat yang menjadi objek penelitian dan berupaya menarik realitas itu ke permukaan sebagai suatu ciri, karakter, sifat, model, tanda atau gambaran tentang kondisi, situasi ataupun fenomena tertentu (Bungin, 2007:68). Pendekatan yang digunakan adalah studi kasus, dimana merupakan penelitian mengenai manusia (dapat suatu kelompok, organisasi maupun individu), peristiwa, latar secara mendalam dan tujuan dari penelitian ini untuk mendapatkan gambaran yang mendalam tentang suatu kasus yang sedang diteliti. Pengumpulan datanya diperoleh dari wawancara, observasi dan dokumentasi (Sujarweni, 2014:22). Studi kasus adalah salah satu strategi dan metode analisis data kualitatif yang menekankan pada kasuskasus khusus yang terjadi pada objek analisis. Dalam analisis studi kasus (seperti halnya analisis kualitatif pada umumnya), peneliti diberi kebebasan membangun struktur tulisan berdasarkan domain yang dikaji serta keinginan-keinginan peneliti tentang domain mana yang dikembangkan (Bungin, 2007:237-238).

\subsection{Lokasi dan Waktu Penelitian}

Penelitian tidak berpusat di satu tempat yang biasanya menjadi objek penelitian karena data yang dioleh merupakan data sekunder yang diperoleh melalui website.Waktu penelitian dilakukan pada bulan Juni sampai dengan Agustus 2016.

\subsection{Jenis dan Sumber Data}

Penelitian ini menggunakan data yang bersifat historis, yakni data sekunder berupa Laporan Realisasi Anggaran Pemerintah Kota Manado tahun 2011-2015 yang dipublikasikan melalui website bpk-bmd.manadokota.go.id.Selanjutnya untuk mencari sumber teori dan pelaksanaannya diperoleh dari riset pustaka dan penelitian sejenis yang dipublikasikan lewat jurnal penelitian.

\subsection{Teknik Pengumpulan Data}

Menurut Sugiyono (2014:62), teknik pengumpulan data merupakan langkah yang paling strategis dalam penelitian, karena tujuan utama dalam penelitian adalah mendapatkan data. Tanpa mengetahui teknik pengumpulan data, maka tidak mungkin akan mendapatkan data yang memenuhi standar data yang ditetapkan. Teknik pengumpulan data yang ditempuh dalam penelitian ini adalah melalui studi dokumentasi (documentation).Penelusuran data dari dokumen-dokumen instansi yang relevan dengan masalah pokok dan materi penelitian sebagai pendukung data penelitian yang tidak diperoleh dalam observasi dan wawancara. Data yang diperlukan dalam penelitian ini ada berupa; gambaran umum Kota Manado dan Laporan Realisasi Anggaran (LRA) Pemerintah Kota Manado Tahun Anggaran 2011 - 2015 serta data lain yang diperlukan terkait dengan metode analisis yang digunakan.

\subsection{Teknik Analisis Data}

Penelitian ini menggunakan Analisis Rasio Keuangan terhadap APBD Kota Manado Tahun Anggaran 2011-2015. Tahap-tahap yang dilakukan dalam menganalisis data ini antara lain:

a. Menghitung rasio keuangan berdasarkan data yang diperoleh dengan membuat tabel.

b. Membuat grafik dari hasil perhitungan rasio keuangan dari setiap periode.

c. Mendeskripsikan data dari hasil perhitungan rasio keuangan atau dengan melihat grafiknya. 


\section{HASIL ANALISIS DAN PEMBAHASAN \\ 4.1. Analisis Kinerja Keuangan Daerah}

1. Rasio Kemandirian

\begin{tabular}{|c|r|r|r|c|}
\hline $\begin{array}{c}\text { Tahun } \\
\text { Anggaran }\end{array}$ & Realisasi PAD & $\begin{array}{c}\text { Bantuan Pemerintah } \\
\text { dan Pinjaman }\end{array}$ & Rasio Kemandirian & Pola Hubungan \\
\hline 2011 & 134.881 .746 .616 & 764.431 .234 .924 & $17,645 \%$ & Instruktif \\
\hline 2012 & 178.429 .310 .832 & 859.069 .263 .894 & $20,770 \%$ & Instruktif \\
\hline 2013 & 215.871 .042 .643 & 989.056 .446 .963 & $21,826 \%$ & Instruktif \\
\hline 2014 & 263.392 .296 .958 & 1.067 .123 .277 .951 & $24,682 \%$ & Instruktif \\
\hline 2015 & 281.112 .682 .436 & 1.444 .428 .089 .690 & $19,462 \%$ & Instruktif \\
\hline
\end{tabular}

\section{Rasio Derajat Desentralisasi Fiskal}

\begin{tabular}{|c|c|c|c|c|}
\hline Tahun Anggaran & Realisasi PAD & $\begin{array}{c}\text { Total Pendapatan } \\
\text { Daerah }\end{array}$ & $\begin{array}{c}\text { Rasio Derajat } \\
\text { Desentralisasi Fiskal }\end{array}$ & $\begin{array}{c}\text { Kriteria Derajat } \\
\text { Desentralisasi Fiskal }\end{array}$ \\
\hline 2011 & 134.881 .746 .616 & 899.312 .981 .540 & $14,998 \%$ & Kurang \\
\hline 2012 & 178.429 .310 .832 & 1.037 .498 .574 .726 & $17,198 \%$ & Kurang \\
\hline 2013 & 215.871 .042 .643 & 1.204 .927 .489 .606 & $17,916 \%$ & Kurang \\
\hline 2014 & 263.392 .296 .958 & 1.330 .515 .574 .909 & $19,796 \%$ & Kurang \\
\hline 2015 & 281.112 .682 .436 & 1.725 .540 .772 .126 & $16,291 \%$ & Kurang \\
\hline
\end{tabular}
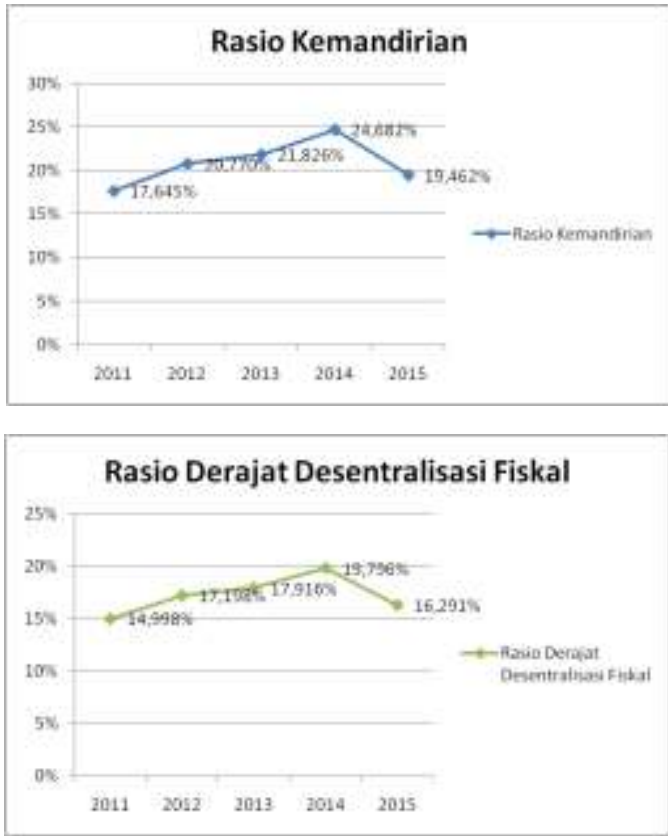

3. Rasio Efektivitas

\begin{tabular}{|c|r|r|r|c|}
\hline Tahun Anggaran & Realisasi PAD & $\begin{array}{c}\text { Target Penerimaan } \\
\text { PAD Berdasarkan } \\
\text { Potensi Riil Daerah }\end{array}$ & Rasio Efektivitas & $\begin{array}{c}\text { Kriteria Rasio } \\
\text { Efektivitas }\end{array}$ \\
\hline 2011 & 134.881 .746 .616 & 163.614 .427 .858 & $82,439 \%$ & Kurang Efektif \\
\hline 2012 & 178.429 .310 .832 & 171.028 .198 .384 & $104,327 \%$ & Sangat Efektif \\
\hline 2013 & 215.871 .042 .643 & 200.716 .511 .942 & $107,550 \%$ & Sangat Efektif \\
\hline 2014 & 263.392 .296 .958 & 257.771 .320 .560 & $102,181 \%$ & Sangat Efektif \\
\hline 2015 & 281.112 .682 .436 & 273.391 .133 .000 & $102,824 \%$ & Sangat Efektif \\
\hline
\end{tabular}

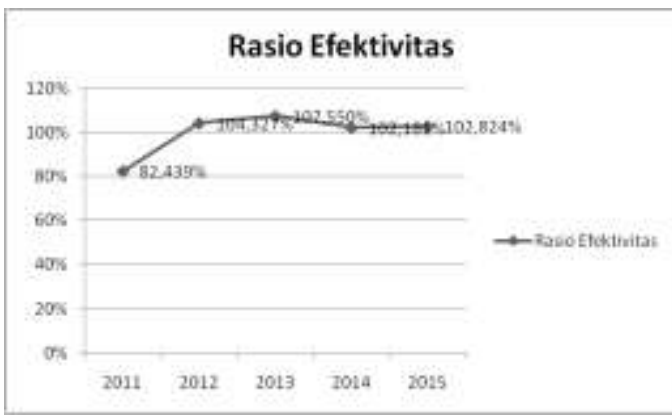

\section{Rasio Efisiensi}

\begin{tabular}{|c|r|r|r|l|}
\hline Tahun Anggaran & $\begin{array}{c}\text { Biaya Yang } \\
\text { Dikeluarkan Untuk } \\
\text { Memungut PAD }\end{array}$ & Realisasi PAD & Rasio Efisiensi & Kriteria Rasio Efisiensi \\
\hline 2011 & 1.704 .820 .500 & 134.881 .746 .616 & $1,264 \%$ & Sangat Efisien \\
\hline 2012 & 2.094 .112 .500 & 178.429 .310 .832 & $1,174 \%$ & Sangat Efisien \\
\hline 2013 & 1.574 .380 .500 & 215.871 .042 .643 & $0,729 \%$ & Sangat Efisien \\
\hline 2014 & 915.759 .000 & 263.392 .296 .958 & $0,348 \%$ & Sangat Efisien \\
\hline 2015 & 1.856 .803 .000 & 281.112 .682 .436 & $0,661 \%$ & Sangat Efisien \\
\hline
\end{tabular}

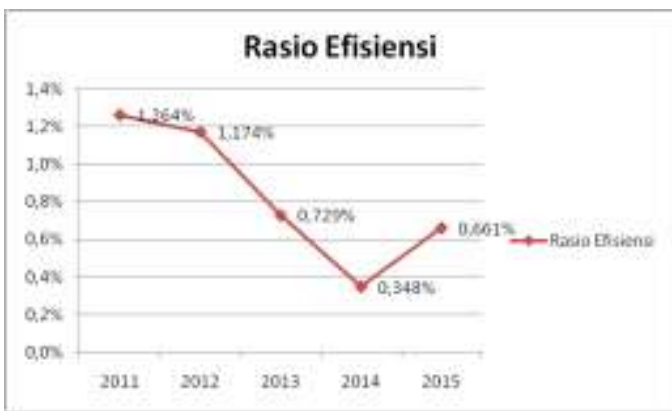




\section{Rasio Keserasian Belanja}

\begin{tabular}{|c|r|r|r|}
\hline Tahun Anggaran & $\begin{array}{c}\text { Total Belanja Tidak } \\
\text { Langsung }\end{array}$ & Total Belanja Daerah & $\begin{array}{c}\text { Rasio Belanja Tidak } \\
\text { Langsung }\end{array}$ \\
\hline 2011 & 554.605 .041 .281 & 876.520 .039 .470 & $63,274 \%$ \\
\hline 2012 & 607.973 .434 .437 & 929.713 .979 .980 & $65,394 \%$ \\
\hline 2013 & 655.146 .312 .022 & 1.087 .436 .304 .582 & $60,247 \%$ \\
\hline 2014 & 762.158 .728 .816 & 1.283 .771 .876 .534 & $59,369 \%$ \\
\hline 2015 & 806.861 .928 .019 & 1.478 .811 .399 .106 & $54,562 \%$ \\
\hline
\end{tabular}

\begin{tabular}{|c|c|c|c|}
\hline Tahun Anggaran & $\begin{array}{l}\text { Total Belanja } \\
\text { Langsung }\end{array}$ & Total Belanja Daerah & $\begin{array}{c}\text { Rasio Belanja } \\
\text { Langsung }\end{array}$ \\
\hline 2011 & 321.914 .998 .189 & 876.520 .039 .470 & $36,726 \%$ \\
\hline 2012 & 321.740 .545 .543 & 929.713.979.980 & $34,606 \%$ \\
\hline 2013 & 432.289 .992 .560 & 1.087.436.304.582 & $39,753 \%$ \\
\hline 2014 & 521.613 .147 .718 & 1.283 .771 .876 .534 & $40,631 \%$ \\
\hline 2015 & 671.949.471.087 & 1.478 .811 .399 .106 & $45,438 \%$ \\
\hline
\end{tabular}

\subsection{Analisis Kemampuan Keuangan Daerah}

\section{Share and Growth}

\begin{tabular}{|c|r|r|r|}
\hline Tahun Anggaran & PAD & \multicolumn{1}{c|}{ Total Belanja } & \multicolumn{1}{c|}{ Nilai } \\
\hline 2011 & 134.881 .746 .616 & 876.520 .039 .470 & $15,388 \%$ \\
\hline 2012 & 178.429 .310 .832 & 929.713 .979 .980 & $19,192 \%$ \\
\hline 2013 & 215.871 .042 .643 & 1.087 .436 .304 .582 & $19,851 \%$ \\
\hline 2014 & 263.392 .296 .958 & 1.283 .771 .876 .534 & $20,517 \%$ \\
\hline 2015 & 281.112 .682 .436 & 1.478 .811 .399 .106 & $19,009 \%$ \\
\hline \multicolumn{5}{|c|}{ Rata-Rata Share } & $18,792 \%$ \\
\hline
\end{tabular}

\begin{tabular}{|c|r|r|}
\hline \multirow{2}{*}{ Tahun Anggaran } & Realisasi PAD & Growth \\
\hline & \multicolumn{2}{|c|}{} \\
\hline 2011 & 134.881 .746 .616 & - \\
\hline 2012 & 178.429 .310 .832 & $132,286 \%$ \\
\hline 2013 & 215.871 .042 .643 & $120,984 \%$ \\
\hline 2014 & 263.392 .296 .958 & $122,014 \%$ \\
\hline 2015 & 281.112 .682 .436 & $106,728 \%$ \\
\hline \multicolumn{2}{|c|}{ Rata-Rata Growth } & $120,503 \%$ \\
\hline
\end{tabular}

\section{Peta Kemampuan Keuangan Daerah}

Dari hasil perhitungan Share dan Growth terhadap LRA Pemerintah Kota Manado Tahun Anggaran 2011 sampai dengan 2015, maka diperoleh data rata-rata Share sebesar $18,792 \%$ dan rata-rata Growth sebesar 120,503\%. Kemudian dengan pemetaan kemampuan keuangan daerah berdasarkan Metode Kuadran, posisi Kota Manado berada pada kuadran II, yaitushare rendah dan growth tinggi. Kondisi ini belum ideal, tetapi daerah mempunyai pengembangan potensi lokal, sehingga PAD berpeluang memiliki peran besar dalam Total Belanja. Sumbangan PAD terhadap Total Belanja masih rendah namun pertumbuhan (growth) PAD tinggi. Ini berarti Pemerintah Daerah Kota Manado masih dapat menggali potensi daerah lebih maksimal, sehingga dapat meningkatkan PAD yang berperan besar dalam APBD.

3. Indeks Kemampuan Keuangan Daerah

$$
\begin{gathered}
\mathrm{IKK}=\frac{\mathrm{XE}+\mathrm{XG}+\mathrm{XS}}{3} \\
\text { Indeks } \mathrm{X}=\frac{0.527+0.539+0.664}{3} \\
\text { Indeks } \mathrm{X}=\frac{1.730}{3}=0.577
\end{gathered}
$$

Dilihat dari hasil perhitungan Indeks Kemampuan Keuangan Kota Manado Tahun Anggaran 2011 sampai dengan 2015, skala indeks menunjukkan angka 0,577. Ini berarti Kemampuan Keuangan Kota Manado tergolong tinggi. Tingginya tingkat kemampuan keuangan Pemerintah Daerah Kota Manado disebabkan oleh besarnya bantuan keuangan dari Pemerintah Pusat yang tercantum pada Analisis Rasio Kemandirian yang menunjukkan bahwa Pemerintah Daerah Kota Manado memiliki tingkat kemandirian yang sangat rendah. 
Hal ini sangat bertolak belakang dengan amanat otonomi daerah yang menuntut kemandirian dan kewenangan Pemerintah Daerah dalam menjalankan urusan rumah tangganya.

\section{KESIMPULAN DAN SARAN}

\subsection{Kesimpulan}

Berdasarkan hasil analisis terhadap kondisi yang dijumpai dalam penelitian, maka kesimpulan yang dapat ditarik dalam penelitian ini adalah sebagai berikut.

1. Berdasarkan hasil perhitungan normatif dan analisis Kinerja Keuangan Daerah dapat disimpulkan, bahwa pola hubungan tingkat kemandirian daerah berada pada kriteria instruktif. Kemandirian Pemerintah Kota Manado berada pada kemampuan keuangan yang masih sangat rendah dalam memenuhi kebutuhan dana untuk penyelenggaraan tugas-tugas pemerintahan, pembangunan dan pelayanan sosial masyarakat. Ini terlihat dari hasil rata-rata Rasio Kemandirian Kota Manado Tahun Anggaran 2011-2015, berdasarkan pengolahan data yang berasal dari LRA Pemerintah Kota Manado Tahun Anggaran 2011-2015 adalah sebesar 20,877\%. Ini menunjukkan bahwa, peran Pemerintah Pusat sangat dominan dalam pengelolaan keuangan Pemerintah Daerah Kota Manado. Mengingat peran Pemerintah Pusat yang masih sangat dominan, wajar jika Derajat Desentralisasi Fiskal Pemerintah Daerah Kota Manado masih kurang. Ini terlihat dari rata-rata Rasio Derajat Desentralisasi Fiskal selama periode 5 tahun yaitu sebesar 17,240\%. Artinya, Pemerintah Pusat memberikan kewenangan dan tanggung jawab yang kecil kepada Pemerintah Daerah Kota Manado. Namun, tingkat efektivitas dan efisiensi pengelolaan keuangan daerah Kota Manado terbilang efektif dan sangat efisien. Ini terlihat dari tingginya nilai rata-rata Rasio Efektivitas yaitu sebesar99,864\% dan rendahnya nilai rata-rata Rasio Efisiensi yaitu sebesar $0,835 \%$ selama periode 5 tahun anggaran. Rasio Keserasian Belanja menunjukkan bahwa antar belanja tidak langsung dan belanja langsung belum seimbang. Terbukti dari perhitungan Rasio Belanja Tidak Langsung dan Rasio Belanja Langsung, Pemerintah Daerah lebih banyak menggunakan dana untuk pengeluaran belanja yang tidak terkait dengan pelaksanaan kegiatan secara langsung daripada belanja yang terkait langsung dengan kegiatan. Semestinya Belanja Langsung lebih besar dari Belanja Tidak Langsung.

2. Berdasarkan hasil perhitungan dan analisis Kemampuan Keuangan Daerah dapat disimpulkan, bahwa kondisi kemampuan keuangan Kota Manado masih belum ideal. Dilihat dari hasil perhitungan share dan growth terhadap LRA Pemerintah Kota Manado Tahun Anggaran 2011 sampai dengan 2015, maka diperoleh nilai rata-rataShare sebesar $18,792 \%$ dan rata-rata Growth sebesar 120,503\%, sehingga posisi Kota Manado berada pada kuadran II yang berarti berada pada kondisi belum ideal. Hal ini berarti, Pemerintah Daerah Kota Manado masih harus menggali lebih dalam lagi potensi yang dimiliki daerah, sehingga dapat lebih meningkatkan PAD yang berperan besar dalam APBD. Dilihat dari hasil perhitungan Indeks Kemampuan Keuangan Kota Manado selama periode 5 tahun, skala indeks menunjukkan angka 0,577 yang berarti kemampuan keuangan Kota Manado tergolong tinggi. Tingginya tingkat kemampuan keuangan Pemerintah Daerah Kota Manado disebabkan oleh besarnya bantuan keuangan dari Pemerintah Pusat yang ditunjukkan pada analisis rasio kemandirian. Hal ini sangat bertolak belakang dengan amanat otonomi daerah yang menuntut kemandirian dan kewenangan Pemerintah Daerah dalam menjalankan urusan rumah tangganya.

\subsection{Saran}

Berdasarkan penarikan kesimpulan yang didapatkan dari hasil perhitungan normatif dan analisis, maka saran yang diberikan peneliti adalah sebagai berikut.

1. Pemerintah seharusnya lebih meningkatkan pengelolaan terhadap potensi daerah yang dimiliki oleh Kota Manado, karena mempunyai dampak yang besar, tidak hanya bagi 
Pemerintah, tetapi juga bagi masyarakat. Potensi tersebut antara lain di bidang jasa, perdagangan dan pariwisata. Jika Pemerintah berhasil mengupayakan pemanfaatan potensi tersebut secara maksimal, maka pajak yang merupakan penopang utama dalam meningkatkan Pendapatan Asli Daerah akan semakin meningkat.Untuk mendukung peningkatan pajak dan retribusi daerah, Pemerintah hendaklah memberi informasi secara rinci kepada masyarakat tentang kewajiban mereka sebagai pembayar pajak dan retribusi daerah, karena tidak semua masyarakat mengetahui rincian kewajiban jumlah pajak dan retribusi daearah yang harus dibayarkan. Pemerintah juga perlu melakukan pengawasan terhadap pihak yang terkait dengan pemungutan pajak dan retribusi daerah supaya tidak terjadi kecurangan. Karena besarnya pajak dan retribusi daerah tidak hanya sebagai komponen utama untuk meningkatkan PAD, tetapi juga sebagai tolok ukur tingkat kesejahteraan masyarakat.

2. Dilihat dari perhitungan Rasio Keserasian Belanja secara normatif, keseimbangan antar belanja belum menunjukkan kata seimbang. Pemerintah Daerah seharusnya lebih cenderung menggunakan dana untuk kegiatan Belanja Langsung yang terdiri atas Belanja Pegawai, Belanja Barang dan Jasa dan Belanja Modal untuk meningkatkan kualitas output, sehingga fungsi anggaran sebagai alat distribusi, alokasi dan stabilisasi bisa berjalan dengan baik. Pemerintah Daerah Kota Manado harus mengurangi ketergantungan terhadap dana bantuan dari Pemerintah Pusat, agar dapat mencapai kondisi tingkat kemampuan keuangan yang ideal. Caranya, dengan mengoptimalkan potensi daerah yang ada untuk meningkatkan Pendapatan Asli Daerah yang dapat digunakan untuk mengurangi besarnya dana bantuan yang diberikan oleh Pemerintah Pusat kepada Pemerintah Daerah.

\section{DAFTAR PUSTAKA}

Badan Perencanaan Pembangunan Nasional (BAPPENAS). 2003. "Peta Kemampuan Keuangan Provinsi Dalam Era Otonomi Daerah”. Direktorat Pengembangan Otonomi Daerah.

Bisma, I Dewa Gde dan Susanto, Hery. 2010. "Evaluasi Kinerja Keuangan Daerah Pemerintah Provinsi Nusa Tenggara Barat Tahun Anggaran 2003-2007”. Jurnal. Mataram:GaneÇ Swara Edisi Khusus Vol. 4 No.3.

Bungin, Burhan. 2007.Penelitian Kualitatif; Komunikasi, Ekonomi, kebijakan Publik dan Ilmu Sosial lainnya. Edisi Kedua. Jakarta: Prenada Media Group.

Departemen Dalam Negeri. 1996. Keputusan Menteri Dalam Negeri Republik Indonesia Nomor 690.900-327 Tentang Efektivitas dan Kemandirian Keuangan Daerah Otonom Kabupaten Kota. Jakarta: Depdagri.

Dwirandra, A.N.N.B. 2011. "Efektivitas dan Kemandirian Keuangan Daerah Otonom Kabupaten/Kota Di Propinsi BaliTahun 2002 - 2006”. Skripsi. Universitas Udayana.

Halim, Abdul. 2007. Akuntansi Keuangan Daerah-Akuntansi Sektor Publik, Jakarta: Salemba Empat.

Halim, Abdul dan Muhammad, Syam Kusufi. 2012. Akuntansi Keuangan Daerah- Akuntansi Sektor Publik, Jakarta: Salemba Empat.

Hruza, Filip. 2015. "Public Sector Organization Financial Ratios' Recent DevelopmentAs A Matter Of Financial Innovation". Investment Management and Financial Innovations, Volume 12, Issue 2, 2015.

Kementerian Dalam Negeri. 2014. Peraturan Menteri Dalam Negeri Republik Indonesia Nomor 37 Tahun 2014 Tentang Pedoman Penyusunan Anggaran Pendapatan dan Belanja Daerah Tahun Anggaran 2015. 
Komite Standar Akuntansi Pemerintahan. 2010. Peraturan Pemerintah Republik Indonesia Nomor 71 Tahun 2010 Tentang Standar Akuntansi Pemerintahan.Jakarta: Penerbit Salemba Empat.

Mahmudi. 2010. Analisis Laporan Keuangan Pemerintah Daerah-Panduan Bagi Eksekutif, DPRD, dan Masyarakat Dalam Pengambilan Keputusan Ekonomi, Sosial, dan Politik.Yogyakarta: Unit Penerbit dan Percetakan Sekolah Tinggi Ilmu Manajemen YKPN.

Mahsun, Moh., Firma, Sulistyowati dan Heribertus, Andre Purwanugraha. 2011. Akuntansi Sektor Publik.Yogyakarta: BPFE.

Pramono, Joko. 2014. "Analisis Rasio Keuangan Untuk Menilai Kinerja Keuangan Pemerintah Daerah (Studi Kasus Pada Pemerintah Kota Surakarta)”. Among Makarti, Vol.7 No.13, Juli 2014. STIE AMA Salatiga.

Rahmatina, Aulia Zhufinsa Nur. 2011. "Analisis Rasio Keuangan Anggaran Pendapatan dan Belanja Daerah Kota Bandung Tahun Anggaran 2005- 2009”. Skripsi. Institut Manajemen Telkom Bandung.

Ramsey, Tina Kim. 2013. "Measuring And Evaluating The Financial Condition Of Local Government". Thesis.Faculty of the Department of Public Policy and AdministrationCalifornia State University, Sacramento.

Ritonga, Irwan Taufiq (Indonesia), Clark, Colin (Australia) dan Wickremasinghe, Guneratne (Australia). 2012. "Assessing Financial Condition Of Local Government In Indonesia: An Exploration". Public and Municipal Finance, Volume 1, Issue 2, 2012.

Sugiyono. 2014. Memahami Penelitian Kualitatif. Bandung: Alfabeta.

Sujarweni, V. Wiratna. 2014. Metodologi Penelitian. Yogyakarta: Pustaka Baru Press.

Susanto, Hery. 2014. "Analisis Kemampuan Keuangan Daerah PemerintahPropinsi Nusa Tenggara Barat”. Jurnal Organisasi dan Manajemen, Volume 10, Nomor 1, Maret 2014,15-26.Universitas Terbuka Unit Program Belajar Jarak Jauh Mataram.

Tudose, Mihaela Brînduşa. 2013. "The Analysis of the Financial Performance of Local Authorities in the Context of Budgetary Constraints". Management \& Marketing Challenges for the Knowledge Society(2013) Vol. 8, No. 3, pp. 553-574.

Ulum, Ihyahul. 2009. Audit Sektor Publik. Jakarta: PT Bumi Aksara.

Wardhani, Andita Puspita. 2011. "Analisis Kinerja Keuangan Pemerintah Kota Salatiga Tahun 2005-2010”. Skripsi. Universitas Kristen Satya Wacana. 